\title{
A more liberal France, a more social Europe? Macron, two-level reformism and the COVID-19 crisis
}

\author{
Daniel Clegg ${ }^{1}$
}

Accepted: 30 January 2022 / Published online: 7 March 2022

(C) The Author(s), under exclusive licence to Springer Nature Limited 2022

\begin{abstract}
Emmanuel Macron was elected President of France in 2017 on a programme that promised to confront the structural antagonism between the country's social model and the liberalising thrust of European integration since Maastricht. His novel political offer combined supply-side reforms at home and the strengthening of the social dimension of the European Union, starting with the operation of European economic governance. And he saw simultaneous and explicitly linked action in both the domestic and European arenas-two-level reformism-as crucial in generating political support for this project. This paper assesses his government's success in realising these objectives, and asks what if anything the COVID-19 crisis changed. Focusing on the crucial case of unemployment insurance, it shows how pre-pandemic reform efforts were complicated by deeply embedded policy legacies and were insufficient to significantly enhance France's leverage at European level. COVID-19 generated some unanticipated momentum behind aspects of Macron's plans for Eurozone reform, but at the same time further complicated both the implementation and the politics of his domestic reform agenda. Overall the French case underscores the challenges of radically reorienting mature welfare states, European economic governance and their interaction, even in the presence of major endogenous and exogenous shocks.
\end{abstract}

Keywords France $\cdot$ Eurozone $\cdot$ Welfare state $\cdot$ Labour market $\cdot$ Unemployment insurance $\cdot$ COVID-19

Daniel Clegg

daniel.clegg@ed.ac.uk

1 School of Social and Political Science, University of Edinburgh, Chrystal Macmillan Building, 15a George Square, Edinburgh EH8 9LD, UK 


\section{Introduction}

The relationship between European integration and the future of the domestic social model has become a major source of political instability in France in recent decades. Deeply committed to the European project, France's traditional parties of government found themselves forced to go along with the constitutionalisation in European economic governance of ever-stricter requirements for fiscal consolidation and structural reform. Lacking any electoral mandate for retrenchment and deregulation, they have, however, struggled to bring France's own debt and deficits under control. Though painful welfare and labour market changes have been implemented since the 1990 s, these have appeared to voters as designed to appease her European partners and the financial markets, stoking hostility to both European integration and globalisation. The repeated perception of a gulf between electoral promises and subsequent policy choice has at the same time contributed to the slow disintegration of the French party system.

The election of Emmanuel Macron as French President in May 2017 as the candidate for a 'start-up' political movement is a widely acknowledged consequence of this political crisis. As this paper argues, however, it also promised to see its causes being confronted head-on. As detailed below, Macron's political project departed significantly from that of his predecessors in relation to the reform of Economic and Monetary Union (EMU), the overhaul of the French social model and, above all, the linkage of the two. Macron has tightly coupled his social policy and European policy agendas politically, and ultimately seeks to re-articulate domestic and supranational policies functionally - an approach that can be referred to as 'two-level reformism'. Though outwardly paradoxical, his simultaneous pursuit of both domestic liberalisation and a more social Europe has been central to this political project.

Neither the novelty nor the intellectual coherence of a political project provides a guarantee of its success, though. As this paper shows, the domestic social policy reforms of Macron's governments have been complicated by inherited policy legacies, while his European agenda has come up hard against the reality of divergent national interests. The positive political dynamic intended to result from two-level reformism has also readily turned negative, undermining French credibility on the European stage and squeezing fiscal space for structural reform domestically. While the unexpected irruption of the COVID-19 crisis opened a window of opportunity for reforms at European level, it also complicated the implementation of major changes to domestic social policies. Overall, the French case illustrates the difficulty of reorienting the extant political-economic dynamics of the multi-level European system even in the context of major endogenous or exogenous shocks.

The paper is organised in four sections. As a basis for assessing developments in the Macron era, the first section critically reviews recent literature on the interplay between EMU and French social and labour market policy development under his immediate predecessors. The following section discusses the novelty of Macron's proposals on European integration and social policy as well as the logic of their articulation in his two-level reformism. The two subsequent sections assess his success in pursuing this two-level agenda before and after the outbreak of the 
COVID-19 pandemic, respectively. At European level, the analysis focuses primarily on French attempts to secure a budget and a permanent fiscal stabilisation mechanism for the Eurozone, while domestically the emphasis is on unemployment insurance reform. The account of Macron's strategy is based on the analysis of political campaigning material, interviews and speeches, while the analysis of domestic and European policy relies on reconstruction of debates and decisions from policy documents and reporting in major national newspapers and other specialised media sources.

\section{Perspectives on the EMU-social model interplay in France}

The story of the growing tensions between France's domestic social and economic policy orientations and her traditional commitment to European integration is well known (Amable 2017; Le Cacheux and Ross 2014; Vail 2015). Briefly, since France was forced to accept an EMU architecture-based around a stability-oriented and rule-based governance system at Maastricht (Howarth and Schild 2017), a model of European economic integration based on domestic supply-side adjustment has come into increasing conflict with the continued preferences of the French electorate for a high level of social spending and against labour market deregulation. Though French-led calls to reorient the EMU architecture in a more pro-growth direction started soon after Maastricht (Jabko 2015: 74), they failed to gain wider European traction. And while there has been significant reform of the French social protection system (Palier 2010) and some liberalisation of employment relations (Baccaro and Howell 2017: chapter 5), France's level of social expenditure-today the highest in Europe-and regulated labour market are still widely seen as key factors in its declining external competitiveness.

Supranational mechanisms of fiscal and wage surveillance were considerably reinforced by reforms to the governance of EMU during the Eurozone crisis (de la Porte and Heins 2015). Though these changes resulted largely from Franco-German deals, neither the Gaullist Nicolas Sarkozy (2007-2012) nor his Socialist successor François Hollande (2012-2017) were able to prevent European economic governance being reshaped largely "in German ordo-liberal, 'austerian' terms" (La Cacheux and Ross 2014: 141). Generally, this outcome is put down to France's declining influence at European level, not least due to its economic weakness relative to Germany (Clift and Ryner 2014; Krotz and Maher 2016). Amable (2017), however, argues that French governing elites have themselves grown increasingly convinced of the need for structural reforms and fiscal consolidation, seeing domestic constraints arising from the current operation of the Eurozone as essentially beneficial. For the Socialists this has gone along with a push by so-called modernisers in the party to reconstruct its social base around a 'bourgeois bloc' of high-skilled middle- and upper-class voters (ibid.).

There is some disagreement in the literature also on the extent to which reform of the French social model decisively accelerated in the shadow of the Eurozone's reinforced post-crisis economic governance regime. Hassenteufel and Palier (2015) 
cite pension reforms implemented under Sarkozy (2010) and Hollande (2014)—in both cases without having been announced in their electoral programmes-as evidence of the growing European influence on social policy development. But they also note continuing space for negotiation with trade unions, and the rootedness of recent changes in all areas in well-established reform trajectories. Others by contrast point to deep liberalising reforms imposed unilaterally and without significant concessions, especially under Hollande (Rathgeb and Tassinari 2020; Syrovatka 2020). The difference in these assessments may in part be due to the more recent analyses including the later years of Hollande's mandate, which were marked by a distinct turn to orthodoxy (Milner 2017). It could also turn on whether the analytical emphasis is on the traditional sectors of the welfare state as opposed to the 'informal welfare state' of employment and wage regulation.

Unemployment insurance (UI) straddles these two realms, and a brief review of policy development in this area up to 2017 can therefore help adjudicate between competing accounts of the EMU-welfare reform nexus in France in the pre-Macron era. UI is also particularly significant because the German Hartz reforms-in which profound restructuring of unemployment protection was the central and most controversial measure-have loomed large in discussions of the types of structural reform that Germany's uncompetitive European partners, France foremost among them, need to emulate (Lux 2016). During Hollande's mandate, UI was also the object of a number of country-specific recommendations (CSRs) addressed to France through the European Semester. In four successive years (2013-2016), French governments were encouraged to take measures to "ensure sustainability of the [UI] system while ensuring that it provides adequate incentives to return to work" (European Council 2013) or "bring the system back to budgetary stability and provide more incentives to return to work" (European Council 2015).

The principal thrust of UI reform in France in these years was distributive recalibration, with enhancements to protection of precarious workers at the expense of some cuts to benefits for higher earners and the older unemployed (Clegg 2021). These reforms might be argued to have improved work incentives, but with unemployment stubbornly above $10 \%$ until the last months of the Hollande Presidency they certainly did not consolidate the finances of the UI system. It has in fact not been in surplus since the start of the financial crisis in 2008, and its average annual deficit across the subsequent decade was $€ 3$ billion. Under Hollande, the cumulated debt of the UI fund also grew from $€ 13.8$ billion in 2012 to $€ 33.6$ billion in 2017. The congruence between policy development and the CSRs received on this issue is thus very limited, and certainly not consistent with French governments having embraced or been forced into internal devaluation.

Uniquely among European countries, in France UI is regulated by national collective agreements between trade union and employer confederations that are then agreed and extended by the Labour Ministry. Though their regulatory autonomy in UI was somewhat eroded under Sarkozy, until recently the authority of the 'social partners' to decide on the main financial and entitlement parameters of the system has been largely undisputed. Even when an opportunity for the Socialist government to assume control of UI arose following the social partners' failure to reach agreement in 2016, its preferred option was to prolong existing rules until new 
negotiations could be organised. This was despite then Prime Minister Manuel Valls and his economy minister-a certain Emmanuel Macron-having each made widely publicised criticisms of these rules when agreed (Barnard 2014; Le Monde/ AFP 2014). While not alone in explaining the resistance to liberalising reforms even in the context of strong external-including EU-pressures, traditional respect of mainstream political elites for the role of the social partners in governing key sectors of the welfare state is an important, and frequently neglected, dimension of French welfare politics. It is also, as discussed below, one area where Macron's break with France's implicit social constitution was especially manifest.

At least judging by the critical case of UI, the structural antagonism between the direction of European economic integration and domestic social policy orientations only deepened under Macron's two immediate predecessors as French President. Moreover, neither managed to escape from the discursive double bind that mainstream governing elites have found themselves in as this antagonism has grown. As Caune et al (2011) show, French political leaders have traditionally told domestic audiences that France drives the construction of Europe while at the same time vaunting the superior qualities of the French social model. This deeply engrained 'boasting approach' deprives them of any way of legitimating domestic reforms that the current course of European integration has increasingly made necessary. However, without undertaking significant domestic reforms, the likelihood of French leaders regaining the influence they claim to have at European level is very low (Vail 2015: 155). Though Macron is not ostensibly humble in his political style, giving up on French boastfulness of this conventional kind has, as shown below, been a crucial discursive precondition for his two-level reformism.

\section{The Macron strategy: Europe, the social model and two-level reformism}

Despite having run for President largely against the mainstream French party system, Macron's programmatic radicalism cannot simply be taken at face value. Though his 2016 autobiography-cum-manifesto was titled Révolution, and "proposed reforming almost everything" (Ross 2019: 78), a rhetoric of transformation is the stock-in-trade of recent Presidential candidates in France; Sarkozy famously promised 'rupture', while Hollande's manifesto was entitled 'change is now'. Macron's archetypal elite biography and service as staff member and then minister in Hollande's administration also cast doubt on his novelty. Some argue that far from a wind of change in French politics, Macron is just the latest and possibly last avatar of the French-style neo-liberalism that has shaped public policy for the last three decades (Amable and Palombarini 2021); a 'President for the status quo' (Hewlett 2017). So just how novel was Macron's political offer in 2017?

The elements of programmatic continuity are most evident in his proposals on the future of European integration. Since Maastricht, it is standard practice for mainstream French Presidential candidates to promise to 'reorient' European integration - and then fail to deliver after election. In an election campaign where the issue of European integration had unprecedented centrality (Schön-Quinlivan 2017), 
Macron positioned himself as the unambiguously pro-European candidate, with the rather classic ambition of reinforcing European integration through revived and rebalanced Franco-German leadership. Significant nonetheless is the emphasis he placed in his manifesto-alongside the more conventional focus on EU trade policy and initiatives oriented towards growth and innovation-on the reinforcement of Europe's social dimension. He, for example, pledged to drive reform of the posted workers directive, a pro-European counterpoint to calls from some candidates on the Eurosceptic extremes to 'abolish' it. Nor does this emphasis on social Europe appear merely a tactical response to the growing importance of socio-economic questions to contestation around European integration (ibid.). Then President of the European Commission Juncker reported after meeting the newly elected Macron that EU social policy was the first topic they discussed, "the first time that a head of state or government begins by addressing such a subject when talking to me" (Stupp 2017).

On EMU reform, the centrepiece of his plans to revitalise the EU, Macron's claim to novelty lies mainly in the scale of his ambitions. Alhough creation of a budget for the Eurozone is a longstanding French demand, Macron's proposals went beyond anything previously envisaged. He advocated a budget that could not only fund future investments and emergency financial support to member states but also offer a permanent stabilisation mechanism to face up to economic shocks (Macron 2017a: Europe). In an interview given shortly after his election he called for a budget corresponding to "several percentage points" of Eurozone GDP (Rettman 2017). His programme also proposed the creation of a Eurozone economy and finance minister with control over the budget and accountable to a Eurozone Parliament (Macron 2017a: Europe).

In relation to social policy, the most oft-remarked characteristic of Macron's ideas is his 'third way' style synthesis of traditional programmatic commitments of the left and the right (Chamorel 2019; Rathgeb and Wolkenstein 2017). There were elements of this in his programme, for example the pledge to streamline the labour code and further decentralise collective bargaining (in line with traditional policies of the right, fiercely opposed by unions) while increasing taxation on shortterm contracts to limit their use (a policy that has been popular on the left, strongly resisted by business) (Freyssinet 2017). Less discussed but more novel is his strategic deployment of the concept of 'universalism', which is marginal to the traditional social policy repertoire of both right and left in France, at least in relation to core social insurance sectors like pensions and UI (Elbaum 2020). For some, this embrace of universalism is of Nordic inspiration (Lefebvre 2018), while others argue Macron's lodestar is instead a residual Beveridgean social model along British lines (Barbier 2019). In any case, universalism provided the basis for Macron to develop a strong critique of the contributory social insurance character of France's social model, which has, however, proved comparatively successful in containing poverty and inequality (ibid.). 'Boasting' the national model this most clearly was not, and marked a distinct contrast with the more conventional narrative of undertaking reforms to 'guarantee the future of our social model' that even his centreright opponent preferred (Fillon 2017).

Macron's pledge to 'create a universal UI' system (Macron 2017a: Emploi, chômage et sécurités professionnelles) translated into concrete promises to extend 
UI coverage to the self-employed as well as introducing the possibility for job quitters to claim benefits once every 5 years. These new entitlements were costed at, respectively, $€ 1$ billion and $€ 1.5$ annually, which it was argued would be "fully financed, and beyond" by savings of around $€ 10$ billion from reduced unemployment (Macron 2017a: Finances publiques). The most radical aspects of his proposals on UI were, however, not in relation to benefits but instead on financing and governance. He committed to entirely abolish employee UI contributions, compensated through an increase in the broader-based, income tax-like general social contribution (CSG). Concomitantly, he said that the state would 'take control' of UI, a policy field which as mentioned has long been regulated in France by the social partners through national collective agreements. If it was rather vague what universal UI would mean for the existing rights of the unemployed, it was therefore crystal clear how it was meant to strengthen to role of the state relative to the social partners in this policy area. "Because it's no longer this or that category of workers who will be covered, because social protection will be less and less financed by contributions and more and more by tax, the state must take responsibility for strategic decisions that it has until now delegated to the social partners" (Macron 2016: 82). The public authorities, he argued, "can't continue to be the silent guarantors of a system which is adrift with the only option of blocking it ... can no longer be simply commentators of compromises ... which don't happen!” (ibid.).

The extent to which this approach to the role of the social partners breaks with the traditional modernising discourse around reform of the French social model should be underlined. At least since the May 1968 events, the need to reinforce the capacity and regulatory role of civil society actors has been a consistent theme in centrist political rhetorical in France (Rosanvallon 2004). While compatible with liberalising reforms in areas of public policy where the state has traditionally had regulatory pre-eminence, such as labour law, this rhetoric has been far harder to square with legislative imposition in areas where the state is traditionally weak and the social partners have well-established policy prerogatives, such as parts of the social protection system (Palier 2002: 352-356). Until Macron, open calls for the "nationalisation' (étatisation) of UI have been made mainly by those- - such as Philippe Séguin, leader of the campaign against the Maastricht Treaty in the 1990s-more broadly opposed to liberalisation. Like the socialists in 2016, previous reformist governments have struggled to reconcile their stated belief in the virtues of social partnership with their simultaneous desire to enhance their steering capacity over social policy, not least to deliver on their European budgetary commitments. Macron's disruptive potential arguably arose less from his challenge to the left-right cleavage than from his apparent willingness to bridge the ideological and programmatic distinctions between liberals and statists that cuts right across it.

A good case can therefore be made that Macron put forward a path-breaking political offer in relation to both European and to domestic social policy reform. But it is particularly in the tight political coupling between the two that the originality of his programme stands out. While it is hardly unprecedented for French political actors to use domestic policy pledges as signals to non-domestic audiences, whether foreign governments or the financial markets, the explicit and very public linkage made by Macron was novel. In unveiling his programme in March 2017, he was 
clear that his domestic reform agenda-including a commitment to meet the 3\% budget deficit target that he had, however, criticised-was meant to "restore French credibility vis-à-vis Germany", to "convince them of a real change and a real capacity, together, for an active investment policy and more solidarity in the Eurozone and in Europe" (Macron 2017b). In stating this so openly, he at the same time made the popular legitimacy of his domestic reforms strongly dependent on his success in advancing his projects at EU level. This is why he emphasised that implementation of his domestic programme and German concessions on EMU reform needed to happen "more or less simultaneously" (Habermas et al 2017: 86).

Macron's emphasis on the need for conjoint domestic and European action went beyond political strategy, however. He also articulated a new approach to the division of labour in the EU between the national and supranational levels (ibid.). For Macron, if member states must forsake traditional commitments to social protection and redistribution to enhance competitiveness and boost activity, so appropriate mechanisms of solidarity and social protection need to be recast at EU level-particularly to counter the rise of nationalist sentiment. Fiscal and monetary expansion in the Eurozone was not therefore being advocated as in the past to help reduce the pressures on France to implement competitiveness-oriented supply-side adjustment- "not just to solve our internal problems", as he put it (Macron 2017c). Rather, a more social Europe was seen as necessary condition for a more liberal France, and vice versa.

Since Putnam (1988), the metaphor of the 'two-level game' is often used for analysis of international relations. In this perspective inter-state negotiations revolve around actors pursing 'win sets' based on dominant domestic interests. As Crespy and Schmidt (2014) have observed, the growing interpenetration of domestic and European arenas makes this model increasingly inadequate in the EU context, where political action often addresses domestic and international constituencies simultaneously. Macron is the personification of this effacement of the boundaries between domestic and European arenas, a fact perhaps best represented symbolically by his playing of the European and not French national anthem on the evening of his election victory. And in the very explicit way he sought to articulate his domestic and European reform programmes, he appeared to be less in the logic of a two-level game than seeking to pursue an ambitious two-level reformism; simultaneous action on both domestic and European policy that sought to recast their functional relationship by leveraging political spill-overs between the two arenas.

\section{From strategy to action}

Though it owed much to the scandal that engulfed the centre-right candidate Fillon when he looked on course to comfortably win the Presidency, and rested on a relatively modest first round score of $23.7 \%$, Macron's eventual victory over far-right candidate Marine Le Pen in the election run-off was decisive. Coupled with his new party's comfortable majority secured in Parliamentary elections, a strong mandate for reform had been obtained. Following an explicit sequencing (Gouvernement Français 2017), overhauling the complex and restrictive labour code ('renovating 
our labour law') was the President's first priority, with UI and training reform to follow. Labour law reform was highly symbolic for Macron, given its polarising potential and the difficulties the outgoing Socialist administration had encountered in this area. As such it was essential for him to keep the reformist unions onside, which helps understand why some backsliding on his broader programmatic commitments quickly became evident, including in the area of UI. Barely a week after the second round of the Presidential elections the leader of the largest trade union confederation noted that the language of 'tripartism' had replaced that of 'nationalisation' in relation to UI, and stated with confidence that "there is no question that [the social partners] will be excluded from defining the rules and from the management of UI" (Laurent Berger quoted in de Comarmond 2017).

With a series of decrees reforming the labour market quickly and relatively painlessly adopted, attention turned after the summer of 2017 to UI. Ahead of a muchdelayed multilateral meeting with the government, all the social partners - the five union confederations and three employer organisations recognised as nationally representative-took the extremely rare step of publishing a jointly authored document, elaborated in the bipartite political group (groupe politique paritaire) of the UI institution. In this they emphasised their "on the ground knowledge of the functioning of the labour market" and "responsible management of the [UI] system" (Unédic 2017: 1). Their document stated pointedly that "any change in UI must build on the basis constituted by the current functioning of the system", and recalled some of its core characteristics (an insurance-based system that protects the income level of each worker; that is guided by principles of inter-professional solidarity; that is based on contributions paid by workers and their employers, independently of unemployment risks etc.) (ibid: 9). Finally, the document expressed their wish that following the discussions to arrive at a shared diagnosis of problems and identify agreed objectives, any changes to the system should be freely negotiated between the social partners.

Faced with this united front, the government felt obliged to ask the social partners to try to negotiate agreements on the key UI 'universalisation' measures that had been included in Macron's programme, as well as on the introduction of an experience rating mechanism (bonus-malus) in UI to discourage the use of short fixed-term contracts, another high-profile election pledge. On all points, the agreement reached in early 2018 diverged significantly from the spirit and ambition of the original proposals. With respect to covering the self-employed, the social partners emphasised both the technical complexity of the issue and the legal risks arising from potential unequal treatment of contributors, concluding therefore that any benefit should be organised outside, and not cross-subsidised by, the main contributory UI system. Regarding job quitters, they proposed highly restrictive eligibility criteria which would limit potential beneficiaries to 14,000-23,000 cases per year for a cost of at most $€ 330$ million, a fifth of what had been costed in Macron's programme. The government wanted a benefit that would be easier to access but with the level and duration capped to keep the costs in check, something the social partners refused as “opening a Pandora's box that would lead to an English-style system of flat-rate benefits" (Ruello 2018). Finally, instead of introducing experience rating the social partners eventually agreed that sectoral-level negotiations in the industries 
most affected by precarious work should try to find tailored ways of stemming it. Though the agreement was universally acknowledged as thin, the governmentagain - felt obliged to follow the recommendations on nearly all points, largely for reasons of social peace (Belouezzane 2018).

On the EU level, the reform of the European directive governing the posting of workers had provided Macron with an early success, albeit only after concessions to secure Spanish and Portuguese approval. On the bigger prize of EMU reform, progress was, however, much more difficult. Macron strategically timed a major speech on Europe delivered at the Sorbonne for just after the German elections in September 2017, attempting to bear on coalition negotiations. But while the risk of the increasingly Eurosceptic liberals entering government failed to materialise, and the Social Democrats could force references on Eurozone reform into the agreement for a Grand Coalition, the underlying balance of political forces made it perilous for Chancellor Merkel to depart much from traditional German positions (Bulmer, this issue).

In June 2018, a joint Franco-German 'roadmap' for the Eurozone was published. Though Merkel appeared to cede to key French demands such as a dedicated Eurozone budget and a fiscal stabilisation mechanism, the declaration was largely symbolic and "full of language that leaves a lot of room for interpretation" (Stierle 2018). The German Chancellor nonetheless swiftly came under sustained attack from the conservative wing of her party (Robert 2018). Led by the Netherlands, 'the frugals' had also already signalled their opposition to significant EMU reform, and were skilled in hollowing out key features of the Franco-German proposals (Schoeller 2021). The European Council in December 2018 reached agreement on a 'budgetary instrument', but in insisting it be included in negotiations for the Multiannual Financial Framework (MFF) ensured that it would necessarily be very limited in scale (Schild 2020). It was to be directed to competitiveness and convergence, but given lack of agreement among member states there was no reference to any stabilisation function. Overall the outcome was well understood in France to be "very far from Emmanuel Macron's original ambitions" (Ducourtieux 2018).

France's leverage in European-level negotiations was not helped by Macron's mounting difficulties domestically. Throughout 2018 his approval ratings fell steeply, and the idea that his government's policies were 'pro-rich' became increasingly well entrenched. From October 2018 an online campaign against fuel tax increases escalated into a full-scale popular revolt, with successive weekends of disorder in French cities (Chamorel 2019). The so-called yellow vest movement cohered mainly around their open loathing of Macron, but had a loose agenda combining fiscal justice, reductions in inequality and direct democracy (ibid). More than $70 \%$ of French expressed sympathy for the movement, a level of support that remained stable until the President eventually announced a large package of concessions to the movement in mid-December (IFOP 2019). The measures - unveiled on the eve of the European Council-included scrapping some of the planned increases in fuel taxes, reversing the rise in the CSG for retired people with pensions below $€ 2000$ per month and increasing in-work benefits, for an overall cost of $€ 8$ to $€ 10$ billion. While they had the desired effect of reducing support for the yellow vests and providing a sharp boost to Macron's approval ratings, these spending commitments, however, meant 
that France would again fail to meet the 3\% budget deficit target in 2018, having managed this in 2017 for the first time in a decade. In Berlin and Brussels, this was inevitably seized upon as evidence Macron could not face down opposition to his domestic reform agenda. The German daily Die Welt ran a story titled "The President is making France into a new Italy" (Ducourtieux and Wieder 2018).

Restoring the credibility harmed by the pay-off to the yellow vests in turn intensified the government's emphasis on the budgetary dimension of other ongoing reforms. By an amendment to the 2018 law that codified the (limited) UI universalisation measures the social partners had earlier agreed, the government forced an early revision of the main UI collective agreement which had originally been scheduled to run to 2020. Though the unions and employer associations were asked to begin negotiations, these were to take place with reference to objectives and financial parameters fixed by the government, a new procedure that sought to reconcile the government's desire for enhanced control of UI and the social partners' demand that their regulatory prerogatives be respected. The 'framing letter' sent to the social partners asked them to find $€ 3$ to $€ 3.9$ billion savings on UI in a three-year period, while also identifying a range of dysfunctions the negotiators were invited to correct (Gouvernement Français 2018). The government's principal target was the possibility for some low earners to receive of UI benefits as a supplement to their wages, which was accused of locking people into precariousness. The focus of the government's objective of combating precarious work had thus shifted decisively from the behaviour of firms to the behaviour of benefit claimants, justifying substantial cuts to, and therefore savings on, UI.

Though the social partners accepted the invitation to negotiate, an agreement ultimately proved impossible given the scale of savings required. In the summer of 2019 the government stepped in to introduce reforms by decree, the first time in nearly four decades that a UI reform had been unilaterally imposed by a French executive (Clegg 2021). Alongside the new entitlements for the self-employed and job quitters, a first set of cuts would take effect from November 2019, with the introduction of degressive UI benefit rates for high earners as well as increased minimum contribution requirements and much stricter rules on linked benefit spells ('rechargeable rights'). A change to the basis for calculating the reference salary of UI claimants, reducing benefit levels especially for workers who cycle frequently between unemployment and short periods of work, was additionally scheduled for April 2020.

This was evidently a far cry from the universalisation of UI. The impact analysis of the reforms (Unédic 2019) showed that while a maximum of 60,000 people would gain UI rights due to the new provisions for job quitters and the self-employed, more than 1.5 million would be negatively affected by the various benefit cuts. Overall, the changes were projected to produce more than $€ 4.6$ billion savings up to 2022 (ibid: 5). Only $7 \%$ of these would result from the introduction of degressive benefits for higher earners, with the bulk due to stricter contribution conditions (48\%) and the new benefit rate calculation formula (45\%), measures which would disproportionately impact the young, low earners and the precariously employed. The changes implemented thus did little to alter the insurance character of the French UI system, but they did make it significantly less inclusive. And though the government's reform on paper delivered on Macron's campaign pledge to penalise employers 
making heavy use of fixed-term contracts, following intense lobbying by businesses the experience rating system introduced was distinctly toothless, with a symbolic rate of variation that would apply only to companies with more than 11 employees in 7 selected sectors, and not before March 2021 (Freyssinet 2019: 8).

\section{COVID-19 and the Macron project}

Macron was a little beyond the mid-point of his Presidency when COVID-19 struck. France has been hard-hit, with as of November 2021 approaching 120,000 confirmed COVID-19 deaths. Three national lockdowns have been enforced, and the $8.5 \%$ fall in 2020 GDP was the third largest in the G7. The public health response to COVID-19 was tardy and initially somewhat chaotic, leading to strong criticism of the government (Rozenblum et al. 2021). Nonetheless Macron's overall popularity increased sharply in the early months of the pandemic, and has subsequently remained consistently above the approval ratings of Sarkozy and, especially, Hollande at the same stage in their mandates (IFOP 2021a). What though have been the implications of COVID-19 for Macron's pre-existing two-level reform project?

The manifest need for a European-level pandemic response provided a window of opportunity for Macron to once again push his ambitions for economic governance reforms. He was the first European leader to demand coordinated EU action in response to COVID-19, calling for an extraordinary European Council in early March 2020 then organising an open letter from a number of heads of state and government advocating a 'common debt instrument'. Given initial reactions to these initiatives, the French strategy quickly settled on reviving Franco-German leadership. The eventual result was a joint Macron-Merkel proposal for a $€ 500$ billion European recovery programme unveiled in May, setting the agenda for the Commission proposal that was in the pipeline. The $€ 750$ billion Next Generation EU (NGEU) package that was agreed in July was shaped by bargaining between member state coalitions across a number of dimensions, but in this process the Franco-German coalition emerged as the clear victor in terms of achieving its negotiation aims (de la Porte and Jensen 2021).

A comprehensive analysis of NGEU is beyond the scope of this paper (see Armingeon et al., this issue), but suffice to say that to forge the joint Franco-German position Macron was forced to retreat some way from his maximalist ambitions. Where he had called in April 2020 for a package worth 5-10 percent of EU GDP, the average annual stimulus from NGEU will be less than 2 percent, and lower still if the portion allocated as loans are not fully taken up (ibid.). Macron would have preferred to bypass the MFF, but operating through the EU budget was a condition of German agreement (Bulmer, this issue). Above all, though Macron argues that a substantial fiscal capacity needs to be permanent feature of the Eurozone's architecture, great pains have been taken in Berlin and Brussels to stress that NGEU is a temporary instrument responding to an exceptional situation (Armingeon et al., this issue).

Although domestic political factors in Germany mattered (Bulmer, this issue), Macron could nonetheless with justification claim credit for having played the lead 
role in pushing the Chancellor into a historic change in the German position that paved the way for a more solidaristic EU response to this crisis. He gave a televised interview on the main French national news programme on the evening after the agreement was reached in Brussels, presenting the recovery plan as "the project on which the French elected me, the project I promised, the project I then presented in September 2017 at the Sorbonne", and speaking of "the most important moment in the life of our Europe since the creation of the Euro" (Elysée 2021). While the reaction of most opposition parties to the agreement was less lyrical and arguably more accurate, there is some evidence that Macron has enjoyed the political pay-off he was hoping for. 'Relations with the EU' is the area in which his record receives by far the highest approval ratings (58\% satisfied), and one of only a few in which satisfaction with his record has increased since 2019 (IFOP 2021b: 11). His approval ratings on this theme are especially high among young people $(75 \%)$ and voters of the left (68\%), including even respondents close to the far-left La France insoumise $(66 \%)$, a party that is vocally critical of EMU and for whose voters the EU is highly salient (ibid: 14).

Domestically, the need to cushion the economic impact of emergency public health measures inevitably led to a pause in Macron's pre-pandemic reform agenda. Like in most European countries, massive deployment of short-time work was the first line of response. After initial hesitation, the implementation of the second stage of the UI reform was also postponed, and the changes introduced in the first phase temporarily reversed. Initially it was planned that full implementation would be deferred to September 2020, but as the severity of the pandemic became apparent this date was repeatedly pushed back, first to January, then April and finally to July 2021. Though the unions called for them to simply be scrapped, the government was always clear of its intention to introduce its cuts to UI benefits at the earliest opportunity. Particularly with a planned pension reform postponed until further notice, the application of the changes in UI was seen as important in demonstrating to centreright voters, but also to Berlin and Brussels, that the government was continuing with reforms despite the crisis (Desmoulières and Bissuel 2021).

Legal challenges by the unions, however, resulted in aspects of the reform first being invalidated by the Council of State on grounds on unequal treatment, and then its planned introduction in July 2021 being suspended for reasons of general interest, given the economic context. Only once the economic recovery appeared sustained, and after planned changes to the benefit rate calculation were considerably softened, could the changes finally be legally implemented, taking effect in October 2021. Though the government seems persuaded that pandemic disruptions have abated sufficiently to make these measures justifiable again, the French population appears less convinced. While $75 \%$ of respondents supported the UI reforms when a poll was conducted in June 2019 (Elabe 2019), a September 2021 poll showed support for their planned implementation from October was considerably weaker, at only 56\% (IFOP 2021c). Macron's most likely opponent in a Presidential run-off in 2022, Marine Le Pen was not slow to try and exploit any sentiment of injustice, calling the reforms a 'social bloodbath' (cited in Furbury 2021). Not only has the pandemic further complicated a reform project that had already strayed far from its initial ambitions, then, but it has also heightened its political risks. 


\section{Conclusion}

Growing tensions between social policy and European integration have been a crucial ingredient in France's deepening political crisis over the last decade. Emmanuel Macron's 2017 election reflected that crisis while promising to confront its causes head-on. His ambitious plan to overhaul France's social model was both an end in itself and a means of enhancing France's capacity to counter the liberalising thrust of European integration. For Macron, a more liberal France and a more social Europe are functionally complementary, and the pursuit of both in tandem has been central to his political project and strategy.

As this paper has shown, however, this novel two-level reformism has proved very challenging in practice. Entrenched domestic policy legacies and the actors who defend them have been impossible to simply circumvent, while the fundamentally opposed interests of France's European partners have been resistant to any amount of charismatic diplomacy. In three pre-pandemic years in office, there was little evidence of the mutual reinforcement that Macron hoped to generate between his domestic and his European policy action. Ultimately the pattern appears a more familiar one; genuine efforts at domestic reforms did not markedly enhance France's ability to effectively challenge Eurozone rules, while attempts to adhere to those rules further complicated domestic reforms.

While COVID-19 has changed many things, Macron's ability to successfully deliver this conjoint package of EU and domestic social policy reform is not one of them. Though the supranational response to the effects of the pandemic has demonstrated some 'European solidarity' in line with his vocal pleas, the battles on the longer-term future of economic governance remain to be fought, never mind won. At the same time, the health crisis has meant that those aspects of the President's domestic social reform programme that have not been shelved are being implemented in a context that greatly increases their political risks. Assuming Macron stands for re-election, it will be harder for him to persuade voters a second time that his vision of a more liberal France counter-balanced by a more social Europe is either attractive or credible.

Acknowledgements For useful comments on earlier versions of this paper, I am grateful to the anonymous reviewers, Jean-Claude Barbier, Clément Brebion, Caroline de la Porte, Elke Heins and Bruno Palier. Any remaining errors of fact or interpretation are mine.

\section{References}

Amable, B. 2017. Structural Crisis and Institutional Change in Modern Capitalism: French Capitalism in Transition. Oxford: Oxford University Press.

Amable, B., and S. Palombarini. 2021. The Last Neo-Liberal: Macron and the Origins of France's Political Crisis. London: Verso.

Baccaro, L., and D. Howell. 2017. Trajectories of Neoliberal Transformation: European Industrial Relations since the 1970s. Cambridge: Cambridge University Press.

Barbier, J.-C. 2019. Changer de catégorie? La mutation du système français de protection sociale engagée en 2017. Paper presented to the meeting of the RT6 network of the French Sociological Association, 27-30 Aug 2019, Aix-en-Provence, France. 
Barnard, P. 2014. La question de l'assurance chômage «doit être reposée», selon Valls. Le Monde, 6 Oct 2014.

Belouezzane, S. 2018. Assurance-chômage: Le government choisit la conciliation. Le Monde, 2 Mar 2018.

Caune, H., Jacquot, S. and B. Palier. 2011. Boasting the national model: The EU and welfare reforms in France. In The EU and the Domestic Politics of Welfare Reforms, ed. P. Graziano, S. Jacquot, S. and B. Palier, 48-72. London: Palgrave Macmillan.

Chamorel, P. 2019. Macron versus the Yellow Vests. Journal of Democracy 30 (4): 48-62.

Clegg, D. 2021. Less dualization, more segmentation: France's labour market model in the early 21st century. Sociologia Del Lavoro 159: 50-70.

Clift, B., and M. Ryner. 2014. Joined at the hip, but pulling apart? Franco-German relations, the Eurozone crisis and the politics of austerity. French Politics 12 (2): 136-163.

Crespy, A., and V. Schmidt. 2014. The clash of the titans: France, Germany and the discursive double game of EMU reform. Journal of European Public Policy 21 (8): 1085-1101.

de Comarmond, L. 2017. Laurent Berger: «Passer à la hussarde sur le Code du travail, ça ne marchera pas». Les Echos, 16 May 2017.

de la Porte, C., and E. Heins. 2015. A new era of European integration? Governance of labour market and social policy since the sovereign debt crisis. Comparative European Politics 13 (1): 8-28.

de la Porte, C. and M. Jensen. 2021. The Next Generation EU: An analysis of the dimensions of conflict behind the deal. Social Policy \& Administration advance online publication 5 Feb 2021 https://doi. org/10.1111/spol.12709.

Desmoulieres, R. and B. Bissuel. 2021. Pourquoi l'exécutif tient autant à sa réforme de l'assurance chômage. Le Monde, 7 Apr 2021.

Ducourtieux, C. 2018. Les Européens devraient acter le principe d'un budget pour la zone Euro. Le Monde, 14 Dec 2018.

Ducourtieux, C. and T. Wieder. 2018. Gilets jaunes: les choix de Macron inquiètent Berlin et Bruxelles. Le Monde, 11 Dec 2018.

Elabe. 2019. Les français et la réforme de l'assurance chômage. June 2019, Paris: Elabe/Institut Montaigne.

Elbaum, M. 2020. L'universalité dans les réformes de la protection sociale: Un terme « à tout faire » qui nuit à la clarté des enjeux et des choix sociaux (1e partie). Revue De Droit Sanitaire Et Social 3: $548-565$.

Elysée. 2021. L'accord décidé au Conseil Européen est sans precedent. https://www.elysee.fr/emman uel-macron/2020/07/21/laccord-decide-au-conseil-europeen-est-sans-precedent-sur-tf1-emmanuelmacron-revient-sur-les-enjeux-et-limpact-de-laccord-pour-la-france. Accessed 05 Nov 2021.

European Council. 2013. Council recommendation of 9 July 2013 on the National Reform Programme 2013 of France and delivering a Council opinion on the Stability Programme of France. 2012-2017. Official Journal of the European Union C217/27.

European Council. 2015. Council Recommendation of 14 July 2015 on the 2015 National Reform Programme of France and delivering a Council opinion on the 2015 Stability Programme of France. Official Journal of the European Union C272/51.

Fillon, F. 2017. La France a besoin d'un projet radical pour sortir de l'ornière. Les Echos, 13 Apr 2017.

Freyssinet, J. 2017. La genèse des ordonnances portant réforme du Code du Travail. Paris: IRES, IRES working paper 02.2017 .

Freyssinet, J. 2019. La situation sociale à la rentrée 2019. Note Lasaire, 26 Oct 2019. Paris: Lasaire.

Furbury, P.-A. 2021. Pourquoi Marine Le Pen joue la carte de la «sensibilité sociale». Les Echos, 15 Oct 2021.

Gouvernement francais. 2017. Programme de travail pour rénover notre modèle social. https://www. gouvernement.fr/sites/default/files/contenu/piece-jointe/2017/06/programme_de_travail_pour_ renover_notre_modele_social.pdf. Accessed 05 Nov 2021.

Gouvernement français. 2018. Programme de travail portant l'orientation pour la réforme de l'assurance chômage. http://www.c2rp.fr/sites/default/files/atoms/files/c2rp-programme-de-travail-reformeassurance-chomage.pdf. Accessed 05 Nov 2021.

Habermas, J., S. Gabriel, and E. Macron. 2017. Quel avenir pour l'Europe? Revue Projet 360: 84-87.

Hassenteufel, P., and B. Palier. 2015. Still the sound of silence? Towards a new phase in the Europeanisation of welfare state policies in France. Comparative European Politics 13 (1): 112-130.

Hewlett, N. 2017. The phantom revolution: The presidential and parliamentary elections of 2017. Modern \& Contemporary France 25 (4): 377-390. 
Howarth, D., and J. Schild. 2017. France and European macro-economic policy coordination: From the Treaty of Rome to the Euro area sovereign debt crisis. Modern \& Contemporary France 25 (2): $171-190$.

IFOP. 2019. Les français et le mouvement des gilets jaunes. January 2019, Paris: IFOP/Fondation Jean Jaures.

IFOP. 2021a. Les indices de popularité Avril 2021. Paris: IFOP/Journal de Dimanche.

IFOP. 2021b. Le bilan d'Emmanuel Macron 4 ans après son élection. April 2021b, Paris: IFOP/FiducialSud Radio.

IFOP. 2021c. Le regard des français sur l'application de la réforme de l'assurance chômage des le 1er octobre, September 2021. Paris: IFOP/Journal de Dimanche.

Jabko, N. 2015. The elusive economic government and the forgotten fiscal union. In The Future of the Euro, ed. M. Matthis and M. Blyth, 70-89. Oxford: Oxford University Press.

Krotz, U., and R. Maher. 2016. Europe's crises and the EU's big three. West European Politics 39 (5): 1053-1072.

Lefebvre, A. 2018. Macron le Suédois. Paris: Presses Universitaires de France.

Le Cacheux, J., and G. Ross. 2014. France in the middle. In European Social Models from Crisis to Crisis, ed. J.E. Dolvik and A. Martin, 105-143. Oxford: Oxford University Press.

Le Monde/AFP. 2014. Assurance chômage: Emmanuel Macron crée des turbulences au sein de la gauche. Le Monde, 12 Oct 2014.

Lux, J. 2016. Disciplining large member states during the crisis: Analysing the discursive strategies of the EU and German actors on France. Critical Policy Studies 12 (1): 44-60.

Macron, E. 2016. Révolution. Paris: XO Editions.

Macron, E. 2017a. Le programme d'Emmanuel Macron. https://en-marche.fr/emmanuel-macron/le-progr amme. Accessed 28 Apr 2021.

Macron, E. 2017b. Présentation du programme. Speech in Paris, Pavillon Gabriel, 2 Mar 2017. https:// en-marche.fr/articles/discours/emmanuel-macron-presentation-du-programme-discours. Accessed 28 Apr 2021.

Macron, E. 2017c. Discours du président de la république-Initiative pour l'Europe. Speech in Paris, la Sorbonne, 26 September 2017. https://en-marche.fr/articles/discours/discours-du-president-de-larepublique-initiative-pour-l-europe. Accessed 28 Apr 2021.

Milner, S. 2017. Employment and labour market policy under the Hollande Presidency: A tragedy in three acts? Modern \& Contemporary France 25 (4): 429-443.

Palier, B. 2002. Gouverner la sécurité sociale. Paris: Presses Universitaires de France.

Palier, B. 2010. The dualizations of the French welfare system. In A Long Goodbye to Bismarck?, ed. B. Palier, 73-100. Amsterdam: Amsterdam University Press.

Putnam, R. 1988. Diplomacy and domestic politics: The logic of two-level games. International Organization 42: 427-460.

Rathgeb, P. and A. Tassinari. 2020. How the Eurozone disempowers trade unions: the political economy of competitive internal devaluation. Socio-Economic Review Advance online publication 30 June. https://doi.org/10.1093/ser/mwaa021.

Rathgeb, P. and F. Wolkenstein. 2017. Third-way à la française: What do Macron's reforms involve and how likely are they to succeed? EUROPP Blog, London School of Economics. https://blogs.lse.ac. uk/europpblog/2017/06/23/third-way-francaise-macron-reforms/.

Rettman, A. 2017. Macron calls for a powerful Eurozone budget. EU Observer, 31 August 2017. https:// euobserver.com/economic/138841. Accessed 28 Apr 2021.

Robert, A. 2018. Strong reactions in Germany against Eurozone reform. Euractiv, 21 June 2018. https:// www.euractiv.com/section/economy-jobs/news/strong-reactions-in-germany-against-eurozonereform/. Accessed 28 Apr 2021.

Rosanvallon, P. 2004. Le modèle politique français: La societé civile contre le jacobinbisme de 1789 à nos jours. Paris: Seuil.

Ross, G. 2019. The French enigma: Macron, centrist reformism and the labor movement. New Labor Forum 28 (1): 76-83.

Rozenblum, S. 2021. France's multidimensional COVID-19 response: Ad hoc committees and the sidelining of public health agencies. In Coronavirus politics: The comparative politics and policy in COVID-19, ed. S. Greer, et al., 264-279. Ann Arbor: University of Michigan Press.

Ruello, A. 2018. Indemnisation des démissionaires: la copie va évoluer. Les Echos, 25 Feb 2018.

Schild, J. 2020. EMU's asymmetries and asymmetries in German and French influence on EMU governance reforms. Journal of European Integration 42 (3): 449-464. 
Schoeller, M. 2021. Preventing the Eurozone budget: Issue replacement and small state influence in EMU. Journal of European Public Policy 28 (11): 1727-1427.

Schön-Quinlivan, E. 2017. The 'elephant in the room' no more: Europe and the structuring line of political cleavage in the 2017 presidential election. French Politics 15: 290-302.

Steirle, S. 2018. Unravelling the Macron-Merkel agreement. Euractiv, 20 June 2018. https://www.eurac tiv.com/section/future-eu/news/unravelling-the-macron-merkel-agreement/. Accessed 28 Apr 2021.

Stupp, C. 2017. Macron praises Juncker's 'social Europe' and posted workers overhaul. Euaractiv, 26 May 2017. https://www.euractiv.com/section/economy-jobs/news/macron-praises-junckers-socialeurope-and-posted-worker-overhaul/. Accessed 28 Apr 2021.

Syrovatka, F. 2020. Labour market policy under the new European economic governance: France in the focus of the new European labour market policy. Capital \& Class advance online publication 25 July. https://doi.org/10.1177/0309816820943177.

Unédic, G.P.P. 2017. Assurance chômage: Socle de réflexion pour une concertation utile. https://www. unedic.org/sites/default/files/2017-12/Document\%20paritaire-Assurance\%20cho\%CC\%82magede\%CC\%81cembre\%202017.pdf. Accessed 05 Nov 2021.

Unédic. 2019. Impact de la réforme de l'assurance chômage 2019. https://www.unedic.org/sites/defau lt/files/2019-09/Note\%20d\%27impact\%20r\%C3\%A9forme\%20de\%201\%27Assurance\%20ch\%C3\% B4mage\%202019.pdf. Accessed 05 Nov 2021.

Vail, M. 2015. Europe's middle child: France' statist liberalism and the conflicted politics of the Euro. In The Future of the Euro, ed. M. Matthis and M. Blyth, 136-160. Oxford: Oxford University Press.

Publisher's Note Springer Nature remains neutral with regard to jurisdictional claims in published maps and institutional affiliations.

Daniel Clegg is Senior Lecturer in Social Policy at the University of Edinburgh. His research focuses on the comparative analysis of social and labour market policies and the politics of welfare state reform. 